\title{
Determination of Trace Elements in the Tamsagbulag and Tagaan Els Crude Oils and Their Distillation Fractions Using by ICP-OES
}

\author{
Jargalsaikhan Sainbayar ${ }^{1}$, Dalantai Monkhoobor ${ }^{2}$, Budeebazar Avid ${ }^{3}$ \\ ${ }^{1}$ Calibration and Testing Laboratory, Civil Aviation Authority of Mongolia, Ulaanbaatar, Mongolia \\ ${ }^{2}$ School of Chemistry and Chemical Engineering, National University of Mongolia, Ulaanbaatar, Mongolia \\ ${ }^{3}$ Institute of Chemistry and Chemical Technology, Mongolian Academy of Sciences, Ulaanbaatar, Mongolia \\ Email: sainbayar.j@mcaa.gov.mn
}

Received October 27, 2011; revised November 30, 2011; accepted December 9, 2011

\begin{abstract}
Thirty one trace elements were determined in the petroleum and its fractions of $200^{\circ} \mathrm{C}-350^{\circ} \mathrm{C}, 350^{\circ} \mathrm{C}-450^{\circ} \mathrm{C}$ and up $450^{\circ} \mathrm{C}$ by inductively coupled plasma optical emission spectrometry. Such analyses are important for technical diagnostics as well as specific sample characteristics. The sample preparation together with an efficient sample introduction allowed a fast quantification of the analytes using calibration curves prepared with analyte organic standards. Trace element occurrences, forms, distributions are examined as well as their implications in terms of reservoir geochemistry, oil refining and environment.
\end{abstract}

Keywords: Trace Elements; Petroleum; ICP-EOS; Fractionation; Tertiary Period; Mesozoi

\section{Introduction}

Crude oil represents a complex mixture containing both organic and inorganic chemical species, being trace metals one group the inorganic components present in this type of matrix [1-3]. Information on trace element concentrations in crude oil is getting increasingly important for the geochemical characterization of source rocks and basins and also to allow corrective actions during crude oil processing [4]. Trace metals have been found in different proportions in different crudes and consequently in their derivatives. Frequently Ni and V are found in largest concentrations contributing to environmental pollution [5-7]. Because of their mutagenic and carcinogenic potential $\mathrm{Ni}$ and $\mathrm{V}$ emissions have been strictly controlled in several countries. In addition, $\mathrm{V}$ is a catalyst poison and causes corrosion in furnaces and boilers during oil processing. The knowledge of the concentration ratio between $\mathrm{V}$ and $\mathrm{Ni}$ in crude oil provides powerful geological information allowing oil-oil and oil-rock correlation and evaluation of the palaeoenvironmental conditions [8] of sedimentation. Other metals, such as $\mathrm{Fe}, \mathrm{Cu}$ and $\mathrm{Zn}$, may also be present in significant amounts. Chemical species of these metals can be partially transferred to fractions (fuels for instance), decreasing their quality and performance.

\section{Experimental}

\subsection{Instrumentation}

A Perkin Elmer model Optima 2000 DV Plasma inductively coupled plasma optical emission spectrometer (axial viewing) was used for this study. The instrument is equipped with a dual echelle monochromator, a RF generator of $40 \mathrm{MHz}, \mathrm{GemCon}$ nebulizer. A peristaltic pump was used to feed the nebulization system with sample solution. An auxiliary gas flow regulator was used to control the flow of $\mathrm{O}_{2}$ into the nebulizer gas. The operating conditions are listed in Table 1 [9].

\subsection{Reagents and Solutions}

All reagents employed were of analytical grade. The kerosene was used as solvent in the test as it provides better detection limits and physical property than others $[10,11]$. ICP Solvent was from Conostan (Ponca City, OK, USA). A multielement organometallic standard (Custom blend, Conoco, Ponca City, OK, USA) with analyte concentration of $500 \mu \mathrm{g} \cdot \mathrm{g}^{-1}$ was used to spike the crude oil samples. Two basin (crude oil of XIX-213, 21, $34,40,25-50$, B 27-42 oil well Tamsagbulag basin and TE 27-5, TE 14-19 oil well Tsagaan els basin.) crude oil samples were used. These crude oil samples were spiked 
Table 1. Operating parameters for ICP OES measurements.

\begin{tabular}{lc}
\hline \multicolumn{1}{c}{ Parameters } & Setting \\
\hline RF power $(\mathrm{W})$ & 1500 \\
Outer argon gas flow rate $\left(\mathrm{L} / \mathrm{min}^{-1}\right)$ & 16 \\
Nebulizer gas flow rate: $\mathrm{Ar}\left(\mathrm{L} / \mathrm{min}^{-1}\right) / \mathrm{O}_{2}\left(\mathrm{~L} / \mathrm{min}^{-1}\right)$ & 0.6 \\
Intermediate Argon gas flow rate $\left(\mathrm{L} / \mathrm{min}^{-1}\right)$ & 0.7 \\
Sample uptake $\left(\mathrm{mL} / \mathrm{min}^{-1}\right)$ & 0.8 \\
Position & -3 \\
\hline
\end{tabular}

with the multielement organometallic analyte standard (Conostan Custom blend).

\subsection{Preparation of Samples and Standard}

After petroleum samples were dewatered by calcium chloride [12], the water is decreased below $0.08 \%$ by determination of Karlo-Fisher method [13]. After dewatering, the petroleum samples were distilled into fractions of diesel $\left(200^{\circ} \mathrm{C}-350^{\circ} \mathrm{C}\right)$, oil $\left(350^{\circ} \mathrm{C}-450^{\circ} \mathrm{C}\right)$ and heavy residue (above $450^{\circ} \mathrm{C}$ ) [14].

For preparation of sample, crude oil and its fractions of $200^{\circ} \mathrm{C}-350^{\circ} \mathrm{C}$ and $350^{\circ} \mathrm{C}-450^{\circ} \mathrm{C}$ were diluted tenfold, above $450^{\circ} \mathrm{C}$ fraction was diluted thirtyfold with kerosene [10].

Conostan Custom Blend standard was spiked to these solutions. Trace elements are determined in samples by comparison standard.

\section{Results and Discussion}

Results of trace elements in petroleum of Tamsagbulag and Tsagaan els basin are shown in Tables $\mathbf{2}$ and $\mathbf{3}$.

About 30 elements between 0.01 - 35.6 ppm were determined in petroleum of Tamsagbulag and Tsagaan Els basin. The $\mathrm{Li}$ is not detected in petroleum of Tamsagbulag and Tsagaan Els basin. The relatively high $\mathrm{Na} 20.98$ ppm in Tamsagbulag, 35.6 in Tsagaan els basin crude oil is noteworthy. This could be incidental due to the contact of crude oil with salt water [16].

Table 2 presents rare earth elements of $\mathrm{Y}, \mathrm{La}$ and $\mathrm{Sc}$ that were determined $0.01-0.07 \mathrm{ppm}$ in petroleum of Tamsagbulag and Tsagaan Els basin. Therefore, it is impossible to use raw material of rare earth elements [3]. Sum trace elements relatively for petroleum of Tamsagbulag and Tsagaan Els, sum trace elements in petroleum of Tamsagbulag more 1.5 than petroleum of Tsagaan Els.

Table 2 shows that alkali and alkaline earth metals are most of all other group elements. It is alkali metals and alkaline earth metals that are related to earth. Elements of Sub-Group IIIa (Sc, Y, La) are the least of all other group elements.

The content of determined elements is possibly stationing for following decreasing states:
Table 2. Concentration of trace elements in petroleum, ppm.

\begin{tabular}{|c|c|c|c|}
\hline Element & & $\begin{array}{l}\text { Tamsagbulag basin } \\
\text { (sample of 6) }\end{array}$ & $\begin{array}{l}\text { Tsagaan Els basin } \\
\text { (sample of 2) }\end{array}$ \\
\hline \multirow{2}{*}{ Alkali metals } & $\mathrm{Na}$ & 20.98 & 35.6 \\
\hline & $\mathrm{Li}$ & $<0.01$ & $<0.01$ \\
\hline \multicolumn{2}{|l|}{ Total } & 20.98 & 35.6 \\
\hline \multirow{5}{*}{$\begin{array}{l}\text { Alkaline earth } \\
\text { metals }\end{array}$} & $\mathrm{Be}$ & 0.05 & $<0.01$ \\
\hline & $\mathrm{Mg}$ & 0.19 & 1.11 \\
\hline & $\mathrm{Ca}$ & 1.78 & 2.63 \\
\hline & $\mathrm{Ba}$ & $<0.05$ & 0.19 \\
\hline & $\mathrm{Sr}$ & 0.46 & 2.43 \\
\hline \multicolumn{2}{|l|}{ Total } & 2.48 & 6.36 \\
\hline \multirow{2}{*}{ Sub-Group Ib } & $\mathrm{Cu}$ & 0.51 & 0.37 \\
\hline & $\mathrm{Ag}$ & 0.03 & 0.04 \\
\hline \multicolumn{2}{|l|}{ Total } & 0.54 & 0.41 \\
\hline \multirow{2}{*}{ Sub-Group IIb } & $\mathrm{Zn}$ & 3.01 & 0.62 \\
\hline & $\mathrm{Cd}$ & 1.65 & 0.26 \\
\hline \multirow[t]{2}{*}{ Total } & & 4.66 & 0.88 \\
\hline & $\mathrm{Sc}$ & $<0.01$ & 0.04 \\
\hline \multirow[t]{2}{*}{ Sub-Group IIIa } & $\mathrm{Y}$ & 0.01 & 0.07 \\
\hline & $\mathrm{La}$ & 0.01 & $<0.01$ \\
\hline \multicolumn{2}{|l|}{ Total } & 0.02 & 0.11 \\
\hline \multirow{2}{*}{ Sub-Group IIIb } & B & 2.88 & 3.18 \\
\hline & $\mathrm{Al}$ & 0.36 & 2.11 \\
\hline \multirow[t]{2}{*}{ Total } & & 3.24 & 5.29 \\
\hline & $\mathrm{Si}$ & 1.35 & 5.76 \\
\hline \multirow[t]{2}{*}{ Sub-Group IVb } & $\mathrm{Sn}$ & 0.23 & 0.71 \\
\hline & $\mathrm{Pb}$ & 0.18 & 1.16 \\
\hline \multirow[t]{2}{*}{ Total } & & 1.77 & 7.63 \\
\hline & $P$ & 0.22 & 0.06 \\
\hline \multirow[t]{2}{*}{ Sub-Group Vb } & $\mathrm{Sb}$ & 0.14 & 0.15 \\
\hline & $\mathrm{Bi}$ & 0.20 & 0.01 \\
\hline \multirow[t]{2}{*}{ Total } & & 0.56 & 0.22 \\
\hline & $\mathrm{Cr}$ & 1.15 & 1.03 \\
\hline \multirow[t]{2}{*}{ Sub-Group VIa } & Mo & 0.39 & 0.29 \\
\hline & W & 2.79 & $<0.01$ \\
\hline \multirow[t]{2}{*}{ Total } & & 4.18 & 1.32 \\
\hline & $\mathrm{Fe}$ & 2.91 & 4.5 \\
\hline \multirow[t]{2}{*}{ Group VIII } & $\mathrm{Co}$ & 0.07 & 0.59 \\
\hline & $\mathrm{Ni}$ & 3.68 & 2.82 \\
\hline \multirow[t]{2}{*}{ Total } & & 6.66 & 7.91 \\
\hline & $\mathrm{Ti}$ & 0.18 & 0.29 \\
\hline \multirow{2}{*}{$\begin{array}{l}\text { Other group } \\
\text { elements }\end{array}$} & $\mathrm{V}$ & 0.56 & 0.97 \\
\hline & $\mathrm{Mn}$ & 0.06 & 0.17 \\
\hline Sum & & 46.12 & 67.43 \\
\hline
\end{tabular}


Table 3. V/Ni ratios in the studied crude oil samples.

\begin{tabular}{lcc}
\hline \multicolumn{1}{c}{ Coefficient } & $\begin{array}{c}\text { Tamsagbulag } \\
\text { basin }\end{array}$ & $\begin{array}{c}\text { Tsagaanels } \\
\text { basin }\end{array}$ \\
\hline $\mathrm{V} / \mathrm{Ni}$ & 0.15 & 0.34 \\
Geological age of rock & \multicolumn{2}{c}{ Mesozoi, teriaty } \\
Depositional environment of source & \multicolumn{2}{c}{ Nonmarine } \\
Oil properties & \multicolumn{2}{c}{ High wax, low sulfur } \\
Maturity & High maturity & Low maturity \\
\hline
\end{tabular}

Oil of Tamsagbulag basin: $\mathbf{N a}>\mathbf{N i}>\mathbf{B}>\mathrm{Zn}>\mathrm{W}>\mathrm{Sb}$ $>\mathrm{Cd},>\mathrm{Si}>\mathrm{Ca}>\mathrm{Cu}>\mathrm{Mo}>\mathrm{Cr}>\mathrm{Fe}>\mathrm{V}>\mathrm{Sn}>\mathrm{Sr}>\mathrm{Al}$ $>\mathrm{P}>\mathrm{Bi}>\mathrm{Pb}>\mathrm{Ti}>\mathrm{Mg}>\mathrm{La}>\mathrm{Ag}>\mathrm{Co}>\mathrm{Mn}>\boldsymbol{B e}>$ Ba $>$ Y.

Oil of Tsagaan ELs basin: $\mathbf{N a}>\mathrm{Si}>\mathbf{B}>\mathbf{N i}>\mathrm{Sb}>\mathrm{Sn}$ $>\mathrm{Ca}>\mathrm{Fe}>\mathrm{Sr}>\mathrm{Al}>\mathrm{Pb}>\mathrm{Mg}>\mathrm{Cr}>\mathrm{Cu}>\mathrm{V}>\mathrm{Zn}>\mathrm{Co}$ $>\mathrm{Mo}>\mathrm{Ti}>\mathrm{Ag}>\mathrm{Mn}>\mathrm{Y}>\mathrm{P}>\mathrm{Sc}>\boldsymbol{B a}>\mathrm{Bi}>\boldsymbol{B}$. In the presented elements of $\mathrm{Na}, \mathrm{Ni}, \mathrm{B}$ in petroleum samples with a higher content and elements of $\mathrm{Bi}, \mathrm{Be}$ in petro-

Table 4. Determined result of containing trace elements in petroleum fractions of study sample, ppm.

\begin{tabular}{|c|c|c|c|c|c|c|c|}
\hline \multirow{2}{*}{ Elements } & & \multicolumn{3}{|c|}{ Tamsagbulag basin } & \multicolumn{3}{|c|}{ Tsagaan ELs basin } \\
\hline & & $200^{\circ} \mathrm{C}-350^{\circ} \mathrm{C}$ & $350^{\circ} \mathrm{C}-450^{\circ} \mathrm{C}$ & $\mathrm{Up} 450^{\circ} \mathrm{C}$ & $200^{\circ} \mathrm{C}-350^{\circ} \mathrm{C}$ & $350^{\circ} \mathrm{C}-450^{\circ} \mathrm{C}$ & $\mathrm{Up} 450^{\circ} \mathrm{C}$ \\
\hline \multirow{2}{*}{ Alkali metals } & $\mathrm{Na}$ & - & 2.76 & 26.05 & - & 3.37 & 36.55 \\
\hline & $\mathrm{Li}$ & - & - & - & - & - & - \\
\hline \multirow[t]{3}{*}{ Total } & & - & 2.76 & 26.05 & - & 3.37 & 36.55 \\
\hline & $\mathrm{Be}$ & - & - & 0.01 & - & - & 0.01 \\
\hline & $\mathrm{Mg}$ & - & 0.02 & 0.36 & - & 0.8 & 1.21 \\
\hline \multirow[t]{3}{*}{ Alkaline earth metals } & $\mathrm{Ca}$ & - & 0.63 & 4.17 & - & 1.09 & 5.24 \\
\hline & $\mathrm{Ba}$ & - & - & 0.1 & - & 0.01 & 0.40 \\
\hline & $\mathrm{Sr}$ & - & - & 1.84 & - & 0.46 & 4.51 \\
\hline \multicolumn{2}{|l|}{ Total } & - & 0.65 & 6.48 & - & 2.36 & 11.37 \\
\hline \multirow{2}{*}{ Sub-Group Ib } & $\mathrm{Cu}$ & - & 0.03 & 0.81 & - & 0.40 & 4.58 \\
\hline & $\mathrm{Ag}$ & - & - & 0.07 & - & - & 0.07 \\
\hline \multicolumn{2}{|l|}{ Total } & - & 0.03 & 0.88 & - & 0.40 & 4.65 \\
\hline \multirow{2}{*}{ Sub-Group IIb Total } & $\mathrm{Zn}$ & - & 0.60 & 6.89 & - & 0.11 & 1.24 \\
\hline & $\mathrm{Cd}$ & - & 0.24 & 2.46 & - & 0.06 & 0.48 \\
\hline \multirow[t]{2}{*}{ Total } & & - & 0.84 & 9.35 & - & 0.17 & 1.72 \\
\hline & $\mathrm{Sc}$ & - & - & - & - & 0.01 & 0.08 \\
\hline \multirow[t]{2}{*}{ Sub-Group IIIa } & $\mathrm{Y}$ & - & - & - & - & 0.05 & 0.15 \\
\hline & $\mathrm{La}$ & - & - & - & - & - & 0.01 \\
\hline \multicolumn{2}{|l|}{ Total } & - & - & - & - & 0.06 & 0.24 \\
\hline \multirow{2}{*}{ Sub-Group IIIb } & B & 0.52 & 1.14 & 4.64 & 0.39 & 1.16 & 4.62 \\
\hline & $\mathrm{Al}$ & - & - & 1.22 & - & - & 4.13 \\
\hline \multirow[t]{2}{*}{ Total } & & 0.52 & 1.14 & 5.86 & 0.39 & 1.16 & 8.75 \\
\hline & $\mathrm{Si}$ & 0.40 & 0.92 & 2.27 & 0.50 & 1.99 & 10.52 \\
\hline \multirow[t]{2}{*}{ Total Sub-Group IVb } & $\mathrm{Sn}$ & - & - & 0.60 & - & - & 1.46 \\
\hline & $\mathrm{Pb}$ & - & - & 0.06 & - & 0.21 & 2.30 \\
\hline \multirow[t]{2}{*}{ Total } & & 0.40 & 0.92 & 2.93 & 0.50 & 2.20 & 14.28 \\
\hline & $\mathrm{P}$ & 0.08 & 0.20 & 0.55 & - & - & 0.13 \\
\hline \multirow[t]{2}{*}{ Total Sub-Group Vb } & $\mathrm{Sb}$ & 0.03 & 0.04 & 0.28 & 0.03 & 0.05 & 0.27 \\
\hline & $\mathrm{Bi}$ & - & - & 0.47 & - & - & 0.03 \\
\hline \multirow[t]{2}{*}{ Total } & & 0.11 & 0.24 & 1.30 & 0.03 & 0.05 & 0.43 \\
\hline & $\mathrm{Cr}$ & - & 1.7 & 3.08 & - & 0.93 & 1.57 \\
\hline \multirow[t]{2}{*}{ Total Sub-Group VIa } & Mo & - & 0.79 & 3.12 & - & 0.13 & 0.51 \\
\hline & $\mathrm{W}$ & - & - & 1.82 & - & - & - \\
\hline \multirow[t]{2}{*}{ Total } & & - & 2.49 & 8.02 & - & 1.06 & 2.08 \\
\hline & $\mathrm{Fe}$ & - & 0.17 & 7.69 & - & 0.43 & 8.98 \\
\hline \multirow[t]{2}{*}{ Group VIII } & Co & - & - & 0.20 & - & - & 1.20 \\
\hline & $\mathrm{Ni}$ & - & - & 10.09 & - & - & 5.74 \\
\hline \multirow[t]{2}{*}{ Total } & & - & 0.17 & 17.98 & - & 0.43 & 15.65 \\
\hline & $\mathrm{Ti}$ & - & - & 0.35 & - & 0.02 & 0.58 \\
\hline Other group elements & $\mathrm{V}$ & - & - & 1.54 & - & - & 2.04 \\
\hline & $\mathrm{Mn}$ & - & - & 0.19 & - & 0.01 & 0.35 \\
\hline Sum & & 2.16 & 8.44 & 80.94 & 2.27 & 11.29 & 99.36 \\
\hline
\end{tabular}


leum samples with lower content.

Some trace elements ratios were constant in petroleum of common source rocks and dependent on the geological age of the rocks and those ratios were used for tracing source effects. $[8,15,17,18]$. In Table $3, \mathrm{~V} / \mathrm{Ni}$ ratios were calculated using determined result of elements.

In Table 3, the petroleum of Tamsagbulag and Tsagaan els contains the rock with the geological age of the tertiary period and mesozoi because the $\mathrm{V} / \mathrm{Ni}$ ratio is $0.15-0.34$ [17]. Also oils of Tamsagbulag and Tsagaan Els derived from lacustrine or non-marine source rocks [8].

In Table 4, the determined results are presented containing trace elements in petroleum $200^{\circ} \mathrm{C}-350^{\circ} \mathrm{C}$, $350^{\circ} \mathrm{C}-450^{\circ} \mathrm{C}$, up $450^{\circ} \mathrm{C}$ fractions samples by ICP-EOS.

In Table 4 shows that elements except of sub-group $\mathrm{IIIb}, \mathrm{IVb}, \mathrm{Vb}$ were not detected in petroleum fraction of $200^{\circ} \mathrm{C}-350^{\circ} \mathrm{C}$. All elements were detected in petroleum fraction of up $350^{\circ} \mathrm{C}$.

From the Figure 1 can see that trace elements are discovered in fraction at $200^{\circ} \mathrm{C}$ to $450^{\circ} \mathrm{C}$ a very little amount. But about 90 - 95 percent of the total trace elements are contained in fraction above $450^{\circ} \mathrm{C}$. Namely, all elements were determined in heavy fraction which was similar to the results in reference [19-23].

\section{Conclusions}

1) Thirty one trace elements were determined in the petroleum and its fractions of $200^{\circ} \mathrm{C}-350^{\circ} \mathrm{C}, 350^{\circ} \mathrm{C}$ $450^{\circ} \mathrm{C}$ and up $450^{\circ} \mathrm{C}$ by ICP-EOS. The $\mathrm{Li}$ is not detected in petroleum of Tamsagbulag and Tsagaan Els basin. Large amounts of $\mathrm{Na} / 20.98-35.6 \mathrm{ppm} /$ in petroleum reveal the contact of petroleum with underground water. Rare earth elements of $\mathrm{Y}, \mathrm{La}$ and $\mathrm{Sc}$ were determined at $0.01-0.07 \mathrm{ppm}$ in petroleum of Tamsagbulag and Tsagaan els basin. Therefore, it is impossible to use as raw material for rare earth elements.

2) The petroleum of Tamsagbulag and Tsagaan els basin contains rocks with the geological age of tertiary period and mesozoi because of $\mathrm{V} / \mathrm{Ni}$ ratio which is 0.15 0.34. Also oils of Tamsagbulag and Tsagaan Els were derived from lacustrine or non-marine source rocks.

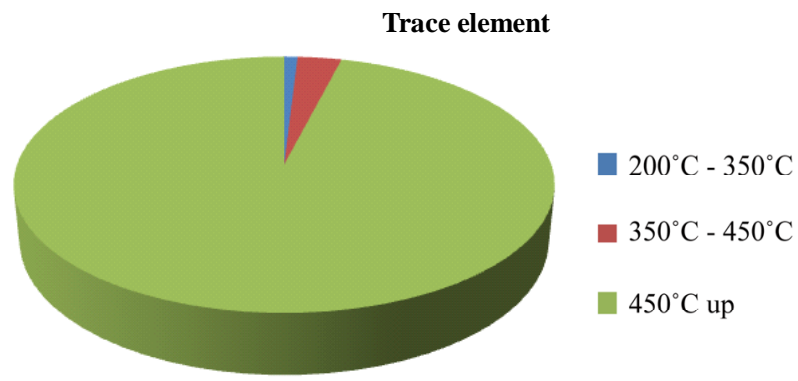

Figure 1. Trace elements in petroleum fractions.
3) About 80 - 90 percent of the trace elements are contained in the fraction above $450^{\circ} \mathrm{C}$. Trace elements in petrochemical products are released during combustion, some of them with harmful effects on human health and environment.

\section{REFERENCES}

[1] E. P. Kalinin, "Geochemical Specificity of Oil and Its Nature," The Bulletin, Vol. 1, 2009, pp. 6-12.

[2] S. B. John and J. W. Wenger, "Metal Content of Twenty-Four Petroleums," Journal of Chemical and Engineering data, Vol. 5, No. 4, 1960, pp. 553-557. doi: $10.1021 / \mathrm{je} 60008 \mathrm{a} 038$

[3] P. F. Gojik, V. A. Kraushkin, V. P. Klochko, E. E. Guseva and R. M. Morozova, "Vanadium and Nickel in Natural Oil Asia, Africa, the Europe, Northern and South America," Ukrain National Academy, Vol. 6, No. 3, 2007. pp. 137-141.

[4] M. S. Roseli, L. S. M. Andri, L. P. S. Carmem and Q. A. Ricardo, "Determination of Mo, Zn, Cd, Ti, Ni, V, Fe, $\mathrm{Mn}, \mathrm{Cr}$ and $\mathrm{Co}$ in Crude Oil Using Inductively Coupled Plasma Optical Emission Spectrometry and Sample Introduction as Detergentless Microemulsions," Microchemical Journal, Vol. 82, No. 2, 2006, pp. 137-141. doi:10.1016/j.microc.2006.01.005

[5] J. Sainbayar, A. Esetjan, T. Tugsuu, G. Sukhdorj and G. Monkhoobor, "Vanadium and Nickel in Oil Tamsagbulag by Spectroscopy," Proceedings of the Mongolian Academy of Sciences, Vol. 2, 2009, pp. 37-45.

[6] H. F. Royston and J. V. B. Gary, "Geochemistry of Metal Complexes in Petroleum, Source Rocks and Coals," American Chemical Society, 1987, pp. 2-16.

[7] N. P. Slotvinskii-Sidak and V. K. Andreev, "Vanadium in the Nature and Technics," Moscow, 1979, pp. 10-24.

[8] A. J. G. Barwise, "Role of Nickel and Vanadium in Petroleum Classification," Energy and Fuels, Vol. 4, No. 4, 1990, pp. 647-652. doi:10.1021/ef00024a005

[9] C. B. Boss and K. J. Fredeen, "Plasma Optical Emission Spectrometry 1999 in USA," 1999, pp. 21-78.

[10] ASTM D 5185, "Standard Test Method for Determination of Additive Elements, Wear Metals and Contaminants in Used Lubricating Oils and Determination Selected Elements in Base Oils by Inductively Coupled Plasma Atomic Emission Spectrometry," 2009.

[11] G. Michael and W. L. Arthur, "Methods Development for Trace Metal Characterization of Crude Oil by Inductively Coupled Plasma Atomic Emission Spectroscopy," Modern Instrumental Methods of Elemental Analysis of Petroleum Products and Lubricants, 1991, pp. 62-69.

[12] I. N. Diyarov, I. Y. Batueva and A. N. Sadikov, "Crude oil Chemistry," Marcel Dekker, Leningrad, 1990, pp. 30-32.

[13] ASTM D 1744, "Standard Test Method for Determination of Water in Liquid Petroleum Products by Karl Fischer Reagent," 1992. 
[14] A. I. Bogomolov, A. A. Gaile and V. V. Gromova, "Crude Oil and Gas Chemistry," SPb, Khimiya, Sankt-Peterburg, 1995, pp. 29-34.

[15] G. L. Bukhbinder, L. N. Shabanova and E. N. Gilibert, "Definition of Microelements in Oil by Atom-Emission Method with Inductive Connected Plasma," Analytical chemistry, Vol. 18, 1988, pp. 1323-1329.

[16] F. Mohammad, B. Ahmed and S. Mohammad, "Trace Metals in Crude Oils from Saudi Arabia," Industrial \& Engineering Chemistry Research, Vol. 22, No. 4, 1983, pp. 691-694. doi:10.1021/i300012a034

[17] M. Salimov, "Heavy Oil and Natural Bitumen Well Forgotten Old Raw Material," 2011. http://msalimov.narod.ru/Vanad.html

[18] A. A. Rumin, M. S. Kopyatkevich and V. V. Gribkov, "About Typification Vanadium Oil," Geology of Oil and Gas, Vol. 6, 1989, pp. 354-357.
[19] V. A. Chakhmachev, E. V. Kurganskaya and S. A. Punanova, "Distribution of Microelements in Oil Fractions," Geochemistry, Vol. 6, No. 2, 1981, pp. 312-316.

[20] S. P. Yakutseni, "Environmental Problems at Development and Development of Oil Deposits," Geology of Oil and Gas, Vol. 1, 2000, pp. 34-40.

[21] G. S. James, "Petroleum Chemistry and Refining," CRC Press, London, 1998, pp. 48-50

[22] V. Alimaa and L. Rui, "Physical and Chemical Properties of Crude Oil and Narrow Fractions of Tamsag Field," The Actual Problems and Decide of the Petroleum Branch of Mongolia, Vol. 1, No. 13, 2007, pp. 10-17

[23] A. V. Kolodchjnii, T. Kh Kovalichuk, U. V. Korovin, V. P. Antonovich, "Definition of Microelement Structure in Petroleum and Petroleum Products. A Condition and Problems," Methods and Objects of the Chemical Analysis, Vol. 1, No. 2, 2006, pp. 90-104. 